Рекомендована д. біол. наук, проф. Л. С. Фірою

УДК 615.31.076:547.792'466.46

DOI 10.11603/2312-0967.2017.1.7541

\title{
REGARDING L-LYSINE 3-METHYL-1.2.4-TRIAZOLE-5-THIOACETATE STANDARDIZATION
}

\author{
L. I. Kucherenko ${ }^{1,2}$, O. S. Bidnenko¹, G. I. Tkachenko ${ }^{1}$ \\ ${ }^{1}$ Zaporizhzhia State Medical University \\ SPA Farmatron, Zaporizhzhia \\ bidnenko2012@gmail.com
}

\begin{abstract}
The aim of the work. Developing the methods of standardization, including identification and quantitative assay, of L-lysine 3-methyl-1.2.4-triazole-5-thioacetate an active pharmaceutical ingredient (API) by physico-chemical methods.

Research Methods. For identification of L-lysine 3-methyl-1.2.4-triazole-5-thioacetate we invited and conducted method of spectroscopic studies. During of operation we selected optimal condition for the analyses of L-lysine 3-methyl-1.2.4triazole-5-thioacetate in different concentration. We picked up concentration for our results that absorption line must be in the UV area $238 \mathrm{~nm}$.

Results and Discussion. The results of the studies show that the absorption characteristic in UV area of L-Iysine 3-methyl-1.2.4-triazolyl-5-thioacetate an shoulder of $238 \mathrm{~nm}$.

Conclusions. We developed methods to identification and quantitative during operation of substance. In further time we have plan to introduce methods of qualitative and quantitative analysis substance to MCQ drugs L-lysine 3-methyl-1.2.4triazolyl-5-thioacetate.
\end{abstract}

Key words: API; L-lysine 3-methyl-1.2.4-triazole-5-thioacetate; standardization; identification; quantitative assay.

Introduction. In recent years, taking into account the growing number of diseases occurring with neurodegenerative changes and involving cognitive functions disorders, an active search for modern, highly efficient, low-toxic, biologically active compounds (drugs with promising endothelial protective and neuroprotective actions) is carried out $[1,2]$.

Today, the range of drugs for treatment of cerebral stroke includes thrombolytics, anticoagulants, and calcium channel blockers, modulators of glutamic receptors, antioxidants, nootropics and neuropeptides. Despite the availability of wide selection of medications, the problem of treatment of cerebral stroke remains valid [3].

Experts of SPA Farmatron together with staff members of Department of Pharmaceutical Chemistry of Zaporizhzhia State Medical University under the leadership of Professor Mazur I. A. synthesized a new compound, which was named as Angiolin (L-lysine 3-methyl-1.2.4-triazole-5-thioacetate). It com- bines fragments of L-lysine and thiotriazoline. In course during the clinical trials the high neuroprotective and endothelial tropic activities were registered $[4,5]$. It is planned to manufacture L-lysine 3-methyl1.2.4-triazole-5-thioacetate in such dosage forms as injections and tablets.

The aim of our study was to develop methods of standardization, including identification and quantitative, of L-lysine 3-methyl-1.2.4-triazole-5-thioacetate in active pharmaceutical ingredient (API) by physico-chemical methods.

Research methods. Today, the great attention is paid to new, modern methods of standardization of substances. Based on the chemical structure of L-lysine 3-methyl-1.2.4-triazole-5-thioacetate (Fig. 1) we developed the methods of analysis of substance.

We used L-lysine-3-methyl-1.2.4-triazole-5-thioacetate series №8 received at Scientific and Technological Corporation of «Institute for Single Crystals»http://zhr.<smiles>Cc1nnc(SCC(=O)O)n1[Hg]CCCCC(N)C(=O)O</smiles>

Fig. 1. L-lysine 3-methyl-1.2.4-triazole-5-thioacetate

ISSN 2312-0967. Фармацевтичний часопис. 2017. № 1 
kharkov.ua/index-e.php, which was obtained with SPA «Farmatron» according to the contract on joint researches. The studied substance is a crystalline powder of white or nearly white color with a weak specific smell, and is hygroscopic substance $[6,7,8]$.

The substance is easily soluble in water, practically insoluble in $96 \%$ alcohol and chloroform.

Pharmacopoeial standard sample (PSS) L-lysine 3-methyl-1.2.4-triazole-5-thioacetate, which was provided by Scientific and Technological Corporation of «Institute for Single Crystals», was used as a standard sample. API:

We offered to use typical reactions in identification of

of sulfur: browning of strips of filter paper wetted solution of lead (II) acetate $R$ in steam of L-lysine 3-methyl-1.2.4triazole-5-thioacetate after heating $[6,8]$.

Results and Discussion. Spectroscopic study was carried out for identification of L-lysine 3-methyl1.2.4-triazole-5-thioacetate. Optimal conditions were selected for the analyses of L-lysine 3-methyl1.2.4-triazole-5-thioacetate in different concentrations. The concentration of studied solution was selected in such a way that the absorption was in optimum 0.2-1A range [9].

Method for quantitative determination: $0.0500 \mathrm{~g}$ (sample weight) L-lysine 3-methyl-1.2.4-triazole-5-thioacetate is put into a volumetric flask of $250 \mathrm{ml}$, is dissolved in $10 \mathrm{ml}$ of distilled water, bring to mark by the same solvent, mix thoroughly. Then $10 \mathrm{ml}$ of the resulting solution is transferred to flask of $25 \mathrm{ml}$ and bring to mark. Absorption is measured at a wavelength $\lambda=238 \mathrm{~nm}$.

The results of studies have shown that the absorption line in the UV area of L-lysine 3-methyl-1.2.4-triazole-5thioacetate has shoulder, namely: $\lambda=238 \mathrm{~nm}$ (Fig. 2).

Determination of PSS of L-lysine 3-methyl-1.2.4-triazole-5-thioacetate was carried out simultaneously under the same conditions. The solution was prepared using the same method as for API of L-lysine 3-methyl1.2.4-triazole-5-thioacetate.

Absorption line in the UV area of L-lysine 3-methyl1.2.4-triazole-5-thioacetate and its PSS are shown in Fig. 2 and Fig. 3.

The percentage of L-lysine 3-methyl-1.2.4-triazole-5-thioacetate was calculated by the formula:

$$
\mathrm{C}_{\%}=\frac{\mathrm{A}_{\mathrm{x}} \cdot m_{0} \cdot 100 \%}{A_{0} \cdot m_{x}}
$$

where $A_{x}$ - absorption of API solution;

$\mathrm{m}_{\mathrm{o}}$ - sample weight of standard sample, $\mathrm{g}$;

$A_{o}$ - absorption of standard sample solution;

$\mathrm{m}_{\mathrm{x}}$ - API sample weight, $\mathrm{g}$

The results of analysis of L-lysine 3-methyl-1.2.4-triazole-5-thioacetate by spectrophotometry are shown in table 1

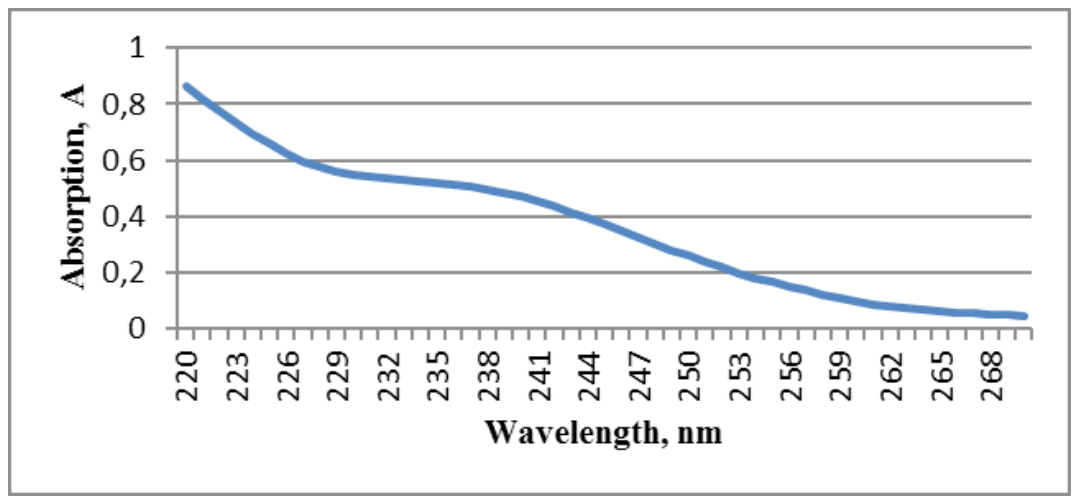

Fig. 2. UV spectrum of L-lysine 3-methyl-1.2.4-triazole-5-thioacetate

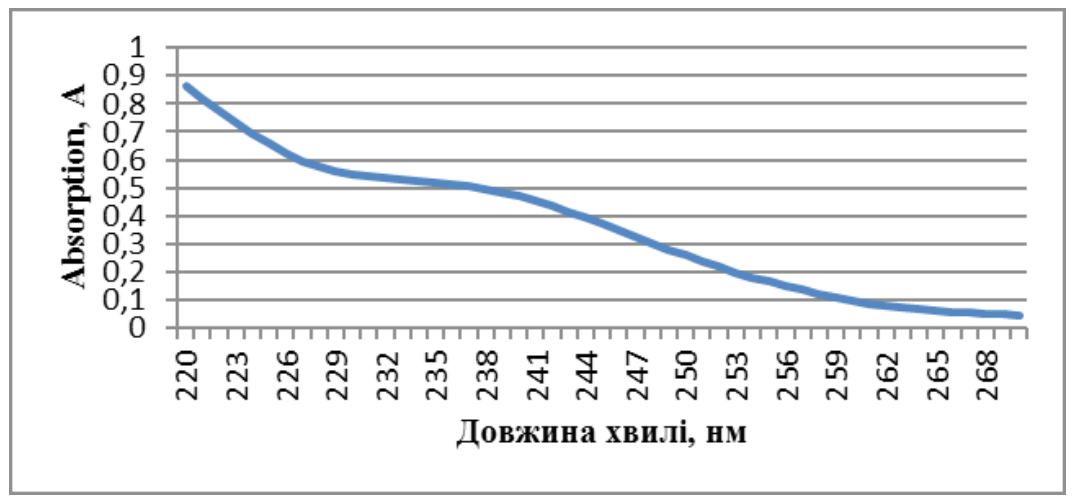

Fig. 3. UV spectrum of PSS of L-lysine 3-methyl-1.2.4-triazole-5-thioacetate 
Аналіз лікарських препаратів

Analysis of drugs

Table 1. The results of analysis of L-lysine-3-methyl-1.2.4-triazole-5-thioacetate by spectrophotometry

\begin{tabular}{|c|c|c|c|c|}
\hline $\begin{array}{ll} & \text { Series №06 } \\
\end{array}$ & Sample weight, $g$ & Absorption, A & Assay, \% & Statistics \\
\hline 1 & 0.0504 & 0.494 & 100.01 & \multirow{6}{*}{$\begin{array}{l}- \\
x=99.99 \\
S^{2}=0.241467 \\
S=0.491393 \\
{ }_{\Delta} x=0.491495\end{array}$} \\
\hline 2 & 0.0501 & 0.498 & 100.40 & \\
\hline 3 & 0.0506 & 0.497 & 99.21 & \\
\hline 4 & 0.0507 & 0.501 & 99.89 & \\
\hline 5 & 0.0504 & 0.498 & 99.80 & \\
\hline 6 & 0.0505 & 0.503 & 100.61 & \\
\hline Comparison solution & $\begin{array}{c}\text { Working standard } \\
0.0500\end{array}$ & 0.495 & & \\
\hline
\end{tabular}

These data show that the results of quantitative determination of L-lysine 3-methyl-1.2.4-triazole-5-thioacetate by spectrophotometry are within acceptable standards of State Pharmacopoeia of Ukraine.

Conclusions: In the course of studies the methods of identification and quantitative determination of L-lysine 3-methyl-1.2.4-triazole-5-thioacetate, which is sensitive, objective, reliable and reproducible were developed.
We have validated the methodology by such indicators as specificity, linearity, range, accuracy, correctness and robustness.

In the future, we are going to include the designed methods of qualitative and quantitative determination of L-lysine 3-methyl-1.2.4-triazole-5-thioacetate in to Quality control techniques in L-lysine 3-methyl-1.2.4-triazole-5-thioacetate dosage form.

\title{
ЩОДО СТАНДАРТИЗАЦІї L-ЛІЗИНУ 3-МЕТИЛ-1,2,4-ТРИАЗОЛІЛ-5-ТІОАЦЕТАТУ
}

\author{
Л. І. Кучеренко ${ }^{1,2}$, О. С. Бідненко ${ }^{1}$, Г. І. Ткаченко ${ }^{1}$ \\ 1Запорізький державний медичний університет \\ ${ }^{2}$ НПО «Фарматрон», Запоріжжя \\ bidnenko2012@gmail.com
}

Мета роботи. Розробка методів стандартизації, зокрема ідентифрікації та кількісного вмісту, L-лізину 3-метил-1,2,4триазоліл-5-тіоацетату в субстанції фрізико-хімічними методами.

Матеріали і методи. Для ідентифрікації L-лізину 3-метил-1,2,4-триазоліл-5-тіоацетату запропоновано та проведено ії спектроскопічне дослідження. B ході роботи були підібрані оптимальні умови здійснення аналізу розчинів L-лізину 3-метил-1,2,4-триазоліл-5-тіоацетату різної концентрації. Концентрацію випробуваного розчину підбирали з таким розрахунком, щоб абсорбція була в оптимальному діапазоні (0,2-1A).

Результати й обговорення. Результати проведених досліджень показали, що крива поглинання в УФ-області L-лізину 3-метил-1,2,4-триазоліл-5-тіоацетату має плече в ділянці 238 нм.

Висновки. У ході проведених досліджень розроблено методики ідентифрікації та кількісного визначення вмісту L-лізину 3-метил-1,2,4-триазоліл-5-тіоацетату. У подальшому розроблені нами методики якісного та кількісного визначення субстанції L-лізину 3-метил-1,2,4-триазоліл-5-тіоацетату планується ввести в Мкя на лікарську фрорму L-лізину 3-метил-1,2,4-триазоліл-5-тіоацетату.

Ключові слова: АФІ; L-лізину 3-метил-1,2,4-триазоліл-5-тіоацетат; стандартизація; ідентифікація; кількісне визначення.

\section{СТАНДАРТИЗАЦИЯ L-ЛИЗИНА 3-МЕТИЛ-1,2,4-ТРИАЗОЛИЛ-5-ТИОАЦЕТАТА}

\section{Л. И. Кучеренко ${ }^{1,2}$, А. С. Бидненко ${ }^{1}$, Г. И. Ткаченко ${ }^{1}$}

${ }^{1}$ Запорожский государственный медицинский университет

${ }^{2} \mathrm{H} П О$ «Фарматрон», Запорожье

bidnenko2012@gmail.com

Цель работы. Разработка методов стандартизации, в частности идентификации и количественного содержания, L-лизина 3-метил-1,2,4-триазолил-5-тиоацетата в субстанции фризико-химическими методами.

Материалы и методы. Для идентификации L-лизина 3-метил-1,2,4-триазолил-5-тиоацетата предложено и проведено ее спектроскопическое исследование. В ходе работы были подобраны оптимальные условия проведения

ISSN 2312-0967. Фармацевтичний часопис. 2017. № 1 
анализа растворов L-лизина 3-метил-1,2,4-триазолил-5-тиоацетата различной концентрации. Концентрацию испытуемого раствора подбирали с таким расчетом, чтобы абсорбция находилась в оптимальном диапазоне $(0,2-$ 1A).

Результаты и обсуждение.Результаты проведенных исследований показали, что кривая поглощения в УФ-области L-лизина 3-метил-1,2,4-триазолил-5-тиоацетата имеет плечо в области 238 нм.

Выводы. В ходе проведенных исследований разработаны методики идентифрикации и количественного определения содержания L-лизина 3-метил-1,2,4-триазолил-5-тиоацетата. B дальнейшем разработанные нами методики качественного и количественного определения субстанции L-лизина 3-метил-1,2,4-триазолил-5тиоацетата планируется ввести в МКЯ на лекарственную фрорму L-лизина 3-метил-1,2,4-триазолил- 5-тиоацетата.

Ключевые слова: АФИ; L-лизина 3-метил-1,2,4-триазолил-5-тиоацетат; стандартизация; идентификация; количественное определение.

\section{Список літератури}

1. Мазур И. А. Метаболитотропные препараты / Мазур И. А., Чекман И. С., Беленичев И. Ф. и др. Запорожье, 2007. - 304 c.

2. Belenichev I. F. The Thiol-Disulfide Balance and the Nitric Oxide System in the Brain Tissue of Rats Subjected to Experimental Acute Impairment of Cerebral Blood Flow: The Therapeutic Effects of Nootropic Drugs / I. F. Belenichev, S. V. Gorbacheva, N. V. Bukhtiyarova // Neurochemical Journal. - 2014. - Vol. 8, № 1. - P. 24-27.

3. White W. Blood pressure monitoring in cardiovascular medicine and therapeutscs / W. White. - New Jersey: Humana Press, 2011. - 308 p.

4. Георгиевский Г. В. Разработка комплекса фризикохимических методик, обеспечивающих создание и контроль качества оригинальных отечественных препаратов, производных 1,2,4-триазола / Г. В. Георгиевский // Запорожский медицинский журнал. - 2011. - T. 13, № 1. - C. 58-69.

\section{References}

1. Mazur IA, Chekman IS, Belenichev IF, Voloshin NA, Gorchakova NA, Kucherenko LI. Metabolitotropic drugs [Метаболитотропные препараты] Zaporozhe; 2007. Russian.

2. Belenichev IF, Gorbacheva SV, Demchenko AV, Bukhtiyarova NV. The thiol-disulfide balance and the nitric oxide system in the brain tissue of rats subjected to experimental acute impairment of cerebral blood flow: The therapeutic effects of nootropic drugs. Neurochemical Journal. 2014;8(1): 24-7. doi:10.1134/S181971241401005X

3. White WB, editor. Blood pressure monitoring in cardiovascular medicine and therapeutscs. 2nd ed. New Jersey: Humana Press; 2011. doi: 10.1007/978-1-59259-978-3

4. Georgievskiy GV. [The development of the complex of physicochemical techniques providing creation and quality control of original domestic drugs, derivatives of 1.2.4-triazole]. Zaporozhskii meditsinkii zhurnal. 2011;13(1): 58-69. Russian.
5. Щодо постадійного контролю виробництва таблеток / Л. І. Кучеренко, О. В. Хромильова, 3. Б. Моряк [ та ін.] // Актуальні питання фрармацевтичної і медичної науки та практики. - 2014. - № 2. - С. 31-34.

6. Державна Фармакопея України: у 3 т / Державне підприємство «Український науковий фрармакопейний центр якості лікарських засобів». - 2-е вид. - Харків : Державне підприємство «Український науковий фрармакопейний центр якості лікарських засобів». - 2016.

7. European Pharmacopoeia. - 6th-ed. Council of Europe. - Strasbourg, 2007. - 3857

8. Компендиум. Лекарственные препараты 2015. / Под ред. проф. В. Н Коваленко. - К. : Морион, 2015. - 1426 с. 9. Ulu S. T. Spectrophotometric method for the determination, validation, spectroscopic and thermal analysis of diphenhydramine in pharmaceutical preparation / S. T. Ulu, F. T. Elmali // Spectrochimica Acta Part A: Molecular and Biomolecular Spectroscopy. - 2010. - Vol. 77, No. 1. - P. 324-329.

5. Kucherenko LI, Khromylyova OV, Moryak ZB, Tkachenko GI, Vashchenko OV. [Stage control of tablets manufacturing]. Aktualni pytannia farmatsevtychnoi i medychnoi nauky ta praktyky. 2014;2: 31-4. Ukrainian.

6. Ukrainian Scientific Pharmacopoeial Center for Quality of Medicines. [State Pharmacopoeia of Ukraine]. 2nd ed., Vol. 1. Kharkiv: Ukrainian Scientific Pharmacopoeial Center for Quality of Medicines; 2015. Ukrainian.

7. European Pharmacopoeia. 6th ed. Strasbourg; 2007.

8. Kovalenko VN, editor. Compendium 2013. Drugs. Kyiv: Morion; 2013. Russian.

9. Ulu ST, Elmali FT. Spectrophotometric method for the determination, validation, spectroscopic and thermal analysis of diphenhydramine in pharmaceutical preparation. Spectrochim Acta A Mol Biomol Spectrosc. 2010;77(1): 324-9. doi: 10.1016/j.saa.2010.05.031. 